\title{
Reaching the Millennial Generation in the Classroom
}

\author{
Paul E. Kotz \\ Brother Louis Hall, Saint Mary's University of Minnesota, USA
}

Copyright $\bigcirc 2016$ by authors, all rights reserved. Authors agree that this article remains permanently open access under the terms of the Creative Commons Attribution License 4.0 International License

\begin{abstract}
The millennial generation (Generation $\mathrm{Y}$ ) is the age group of children born between 1982 and 2002 . Students aged 15 to 16 were asked to answer questions regarding their classroom experience. Sixty eight students were asked to participate in the survey and 63 gave consent for their participation. A qualitative survey approach was used asking three open ended questions, which yielded some fascinating findings, which complement the research that has been done on millennials. When a saturation point was reached, transcribing the same issue multiple times, the results were compiled and listed in narrative form. From this open-ended survey, and transcription of data, the results yielded that this group has a preference for order, safety and security, expect to talk more, and have engaging experiences while learning at the same time. Millennial students say they want to use the creative side of their brain. In the context of assisting teachers in the classrooms and future courses, instructors must realize that this millennial generation needs to be nurtured, mentored, developed, and released to grow in their own learning.
\end{abstract}

Keywords Millennial, Qualitative, Creative, Mentoring, Engagement, Classroom, High School, Education, Teaching, Generation, Higher Education, College, University

\section{Introduction}

As an educator who has worked with high school for 15 years and universities for 23 years, I am continually trying to understand how to address the requests of the various current student sets. It is my desire to be aware and adjust my teaching style to make learning for these students richer and more accessible.

To this end, I asked 63 students within three independent sections of a private Midwest high school aged 15 to 16 to answer three survey questions regarding their classroom experience: 1. What could we as teachers do differently to make a student's experience better in the classroom? 2. What other tools do students need to be successful in the classroom? And 3. Finally, what could I personally do better as a teacher? I chose to focus on the first two questions for this article, reviewed and categorized the common ideas these students shared, and linked these themes with current research regarding millennials. I share these qualitative findings with the reader on teaching methods germane to the millennial student to shed additional light in management and marketing classrooms; these young millennials will likely be the target group in our college and graduate schools.

\section{Background - Reaching the Millennial Generation in the Classroom}

The millennial generation (also known as Generation Y) is the age group of children born between 1982 and 2002, some 81 million children who have taken over $\mathrm{K}-12$, and have entered college and the workforce (Manning, [4] , p.1). This generation will replace the Baby-boomers as they retire.

Although this generation is not so very different from previous cohorts in the way they act and react to the world, they do have unique characteristics, some superficial, and some more deep-rooted. For example, millennials do not wear watches; because they all own cell phones that have this feature. Many do not read the newspaper, but prefer to acquire news on-line. Pictures taken by millennials are digitally stored and often placed on Facebook, or other social media. K-12 education, colleges and universities must adjust to the unique qualities of the millennial generation. This adjustment will aid millennials to become successful students in the classroom by educating in a way that is relevant and caters to their desire to engage in technology with educational tools and social media know-how.

As an educator who has worked with high school for 15 years and universities for 23 years, I am continually trying to understand how to address the requests of the various current student sets. It is my desire to be aware and adjust my teaching style to make learning for these students richer and more accessible.

\section{Literature Review}

Research indicates Millennials possess certain distinct 
characteristics.

The research indicates millennials desire having a closer relationship with parents. According to Elliott-Yeary [2], they admire their parents more than celebrities in $33 \%$ of the cases (p. 2). Millennials have grown up with a closer sphere of influence than ever before. Because they have grown up in a more dangerous world, society has created an environment where they are more sheltered, structured and live in a very protective atmosphere (Wilson and Gerber, [6], p.30).

These students want a close relationship with their teacher involving more guidance and extra personal attention. This group seems more respectful of others because they have grown up in a much more diverse world and a culture where "tolerance" is highly valued. Millennials have grown up in a society surrounded by different religions, races, ethnicities, and cultures. This may have contributed to more respect for these differences. In a crowded world where there are larger numbers of people in classrooms and activities, civility becomes even more essential to getting along and getting the most out of their education.

Some college administrators believe that many Gen Y's have "lost the sense of pure play." According to Allen [1], "They expect everything to be planned for them and do not expect to have as much freedom - or responsibility for structuring their educational lives" (p. 58). Wilson and Gerber [6] noticed that having spent a large percentage of time in structured activities, Millennials are accustomed to having a large amount of adult supervision. Thus, they may have poor self-management and conflict resolution skills (p.32).

Sometimes faculty finds the lack of authoritarian hierarchy in their study groups creates ambiguity concerning having a point of contact for information. At the same time, this group is open and eager to new experiences.

Students are responsive and "very smart" according to some faculty. Members of this cohort set the bar high for themselves, and they, like their Boomer parents, expect success. They sometimes "expect" to get good grades and are upset when this does not happen. As of 2002 , " $81 \%$ of college mental health service directors reported an increase in students with serious psychological problems" (Gallagher, [3]). Some counselors have identified these psychological problems as a result of the overwhelming pressure on students to succeed. The millennial group juggles many tasks at once. This generation often listens to music, works on the computer and watches television at the same time. This means they have come to expect stimulation in their learning environments and may be more focused than it seems to their teachers.

This group is socially conscious. There has been a resurgence of interest in politics and social issues among these young people. Lynch [4] reported, "70\% of first-year students came to campus already registered to vote and $93 \%$ voted in the 2004 presidential election."

Millennials want to know what is expected and what criteria will be used to evaluate their performance. They are very likely to ask questions like, "Will this be on the test?" or "How is this going to affect my life in a positive way?" Certainty and security is vital for this group. Tying learning outcomes to economic objectives is important for millennials.

Members of this group are motivated to learn ways of reducing stress and increasing their marketability. They place high value on developing good interpersonal skills and in getting along with their peers. It is a generation of readers, so written information works well with this group. Electronic books have in many cases replaced hard copies, and this group is adjusting to this new form of media.

\section{Methodology}

To this end, I asked 63 students within three independent sections of a private Midwest high school aged 15 to 16 to answer three survey questions regarding their classroom experience: See Appendix A. 1. What could we as teachers do differently to make a student's experience better in the classroom? 2. What other tools do students need to be successful in the classroom? And 3. Finally, what could I personally do better as a teacher? I chose to focus on the first two questions for this article, reviewed and categorized the common ideas these students shared, and linked these themes with current research regarding millennials. I share these qualitative findings with the reader on teaching methods germane to the millennial student to shed additional light in management and marketing classrooms; these young millennials will likely be the target group in our college and graduate schools.

A qualitative survey approach was used asking three open ended questions, which yielded some fascinating findings, which complement the research that has been done on millennials. When a saturation point was reached, transcribing the same issue more than seven times, the results were compiled and listed in narrative form below. A population of 68 students was survey, and 63 participated anonymously in this convenience sample. Three sections of students aged 15 to 16 were surveyed for a Midwestern high school.

\section{Results - What the Survey Revealed in the Data}

Question 1: What Could We as Teachers Do Differently to Make Their Experience Better in the Classroom?

Young millennials aged 15-16, see the world in a completely different fashion than their Baby Boomer and Gen X predecessors. Millennials possess a wide array of talents and desire for creative outlets in the arts, hands-on activities, interactive games, video lectures, instructional demonstrations, field trips, colored worksheets and projects. 
Millennials also have a desire to learn in a more competitive fashion through games and interactive media.

Like most previous generations, millennials dislike homework but wish to be actively engaged in class and use their time wisely. Wilson and Gerber (2008) recognize millennials prefer to work in small groups with music playing in the background instead of working alone in a silent classroom. Stimulation is a motivator for many in this generation (p.34).

This group has a preference for order, safety and security. They expect to talk more and have engaging experiences that allow them to learn at the same time. Staying interested is vitally important to this group. As always, there are individual members of this generation who like to work independently and do not like to present in class. In surveys given to these young students, time and time again they emphasize making things fun and more "interesting." At the same time, they see the need for maintaining a quiet time to hear instructions and brief lectures to initiate the tasks for the day. Silence and the ability to have clear, complete notes is still a prerequisite for success. They have no problem with being active thinkers within their preferred environment. They express a need to see honesty and understand why things are the way they are.

Millennials are a group that values individual attention and ideas that are fully explained. Students ask for shorter assignments that include more depth and prefer homework assignments that are spaced out with flexible time. They strongly favor activities over lectures. Repetition to enable mastery is a desire for this group. If an activity does not particularly suit their interest, a teacher or facilitator may lose students' focus. Students ask for teachers to facilitate their note taking so that they can remain organized. This group expects mentors and adults to have patience with them and remain flexible.

Millennial students critique their own peers saying their generation is not very focused. Some have asked instructors to close the doors to experience fewer distractions from people in hallways. They acknowledge that each of us has different learning styles, but smaller groups are more attractive to them than large groups or working individually. Some students suggest they need to be more positive, determined, motivated, disciplined and possess more self-control; they do not want to cause distractions for the facilitator/teacher.

Question 2: What Other Tools Do They Need to Be Successful in the Classroom?

Millennial students say they want to use both sides of their brain, especially their creative side. Some say they want to do what is enjoyable in their own estimation. They asked for more comfortable chairs because they sit in classrooms, in many cases, for six to seven periods per day. Comfortable, welcoming and flexible spaces are very important to this group.

Since they employ laptops, they wish for schools to find additional, better ways to learn online. When videos and movies have relevance to the course, students appreciate the opportunity to do this media learning at home followed by the opportunity to ask questions in the next class (flipped curriculum). Students recognize their own visual learning skill and wish instructors would recognize this and teach to this style. Students repeatedly request more interactive materials, additional visuals and more personal involvement.

Students also want to ensure fairness, want to matter in the group, and be acknowledged for their strengths. A cluster of this generation enjoys interactive games, quizlets, and other approaches that help review concepts in alternative forms to lecture. They ask for open notes on examinations, and more hands-on activities. They wish for adults to have patience with their active "multilayered brains," and that teachers would be sympathetic to their need to know why and how projects are to be done. They do not like to rush through lessons. This includes longer review sessions and the desire for thoroughness.

Some students say that teachers or facilitators should do a better job of staying on topic. While in the minority, some students have said that computers should not be allowed in the classroom. While they are similar to students of previous generations, they have used technology since they were infants, and are "wired" as no other previous group of students. This presents particular challenges and opportunities in teaching to millennials.

\section{Conclusions - How Do We Teach to This Group?}

Keeping this group interested by introducing a topic that taps into a personal interest is a primary way of reaching millennials in an educational format. Students repeatedly comment that relating lessons to topics of interest makes their learning experience that much better. This can be problematic because it is difficult for one or two instructors in a classroom to meet the personal interests for each individual. Lynch [4] emphasizes "there is a growing mismatch between faculty and students in terms of teaching and learning."

Small group discussions, projects, in-class presentations and debates, peer critiques, team projects, service learning, field experiences, developing simulations, and case method approaches have been found to be successful for high school and college millennial students. Millennial students seem to thrive when they excel collaboratively while still keeping their unique personal approaches intact.

The development of "learning communities," (small groups of students who can discuss and analyze readings and assignments) is beneficial and should be encouraged. These learning communities also address the need of many millennial students for hands-on activity in the classroom. Having grown up in a highly structured world, this group prefers cohesiveness to ambiguity. Millennials look for such structure in their learning settings. They want to know 
precisely what is required, when work is due, and very specific information about expectations.

Providing frequent feedback is essential for Generation $Y$ to move to the next step and progress as learners. This feedback allows them to know when they are headed in the right direction and when they are getting off-track. Frequent attention from teachers is welcome. According to Elliot-Yeary [2], "Millennials want to enjoy their learning. If it is not fun, it will be cast into the category of boring and may become less effective." Millennials learn best when they are entertained.

This group wants to fully employ their talents. This is a generation that likes to be useful and helpful. When students know more about a topic an instructor might allow them discuss it in depth.

\section{Recommendations}

Tying learning tasks to real-world problems is essential to these learners. If a subject is not seen as relevant, there may be resistance to learning. The need for connections between applications in the world and practice continues to be a theme of which this generation approves. These students also value convenience and want supplies to be readily available in the classroom.

Additional recommendations might include answering some of the following questions: How are these unique to this generation versus others? After an examination of both survey questions and the research, the question must still be addressed: What makes these people tick? Are people's learning needs truly the same no matter what generation they come from?

The millennial generation may need more discipline and the realization that satisfaction does not come quickly, but with hard work. In the context of business management and marketing courses, the adults of the earlier generations may remember what it was like to arrive at young adulthood. They must also realize that this millennial generation needs to be nurtured, mentored, developed, and released to grow in their own learning. According to Elliot-Yeary [2] "This generation is as comfortable with technology as a fish is with water." The hybrid models cropping up at many colleges and universities offer flexibility to learn in the brick and mortar environment on one weekend, and work on-line the next. This may give the working professional a chance to use both technology and interpersonal skills with other colleagues in face-to-face dialogue and collaboration. At the same time, this technology does not necessarily change the student, just the perspective of the learning.

\section{Appendix}

\section{Survey Instrument}

1. What could we as teachers do differently to make a student's experience better in the classroom?

2. What other tools do students need to be successful in the classroom?

3. Finally, what could I personally do better as a teacher?

Note: I chose to focus on the first two questions for this article, reviewed and categorized the common ideas these students shared, and linked these themes with current research regarding millennials.

\section{REFERENCES}

[1] Allen, Christopher (2012). Generational Teaching: Motivating the Minority, $1^{\text {st }}$ ed. Retrieved June 1st, 2013, from http://books.google.com/books?id=77HNPGzfVSUC\&pg

[2] Elliot-Yeary, Sherri. (2012). Generation Y- The Millennial Generation. Generational Guru. Retrieved May 25, 2013, from http://generationalguru.com/2012/02/generation-ythe-millennial-generation/

[3] Gallagher, R. (2008). National Survey of Counseling Center Directors. The International Association of Counseling Centers, Inc. Retrieved January 10, 2009 from http://www.iacsinc.org.

[4] Lynch, Art. (2013). Generation Me! The Millennial Generation. Retrieved May 28, 2013 from http://www.comp rofessor.com/2009/12/millenial-generationers-are-changing. html

[5] Manning, Terry M (2013). Who are the Millennials? Central Piedmont Community College. Retrieved May 24, 2013, from https://www.cpcc.edu/millennial.

[6] Wilson, Michael, \& Gerber E. Leslie. (2008). How Generational Theory Can Improve Teaching: Strategies for Working with the "Millennials" [Electronic Version]. Currents In Teaching And Learning, 1, 29-39. 